\title{
Design-Integrated LCA Using Early BIM
}

\author{
Alexander Hollberg, Julia Tschetwertak, Sven Schneider \\ and Guillaume Habert
}

\begin{abstract}
Life Cycle Assessment (LCA) is increasingly used for buildings, however, mostly for post-design evaluation of the environmental impact. To use the results for optimization, LCA has to be integrated in the early design stages. While Building Information Modelling (BIM) is more and more applied in detailed design stages, simple 3D models are typically used to compare design variants in early stages. The objective of this paper is to introduce a simplified, design-integrated method based on these early BIM models with limited information. The early BIM-LCA method uses simple 3D geometry and a parametric LCA model. Methodological simplifications are introduced and a single indicator based on the certification system of the German Sustainable Building Council (DGNB) is used to provide an intuitive real-time feedback for the designer. The method is applied to the conceptional design of a residential neighbourhood. The results highlight the great potential of using simplified LCA to quantify environmental performance for decision-making in early design stages.
\end{abstract}

\section{Introduction}

Life Cycle Assessment (LCA) is increasingly gaining importance for environmental evaluation of buildings, mostly in the form of building certification labels. The application of LCA at a late stage of the planning process for post-design evaluation of the environmental impact is not sufficient on its own if the results are not used to improve the design [1]. The highest optimization potential lies within the early design stages where the decisions made have the biggest influence on energy

\footnotetext{
A. Hollberg ( $\square) \cdot$ G. Habert

Chair of Sustainable Construction, IBI, ETH Zürich, Stefano-Franscini-Platz 5, 8093 Zurich, Switzerland

e-mail: hollberg@ibi.baug.ethz.ch
}

A. Hollberg · J. Tschetwertak · S. Schneider

Bauhaus University Weimar, Geschwister-Scholl-Straße 8, 99423 Weimar, Germany

(C) The Author(s) 2018

E. Benetto et al. (eds.), Designing Sustainable Technologies,

Products and Policies, https://doi.org/10.1007/978-3-319-66981-6_30 
demand [2] and environmental impact [3] while featuring the smallest costs for changes to the design [4]. Optimization in these early design stages can only be achieved by generating and comparing design variants. To allow for design-integrated assessment of the environmental performance a simplified and time-efficient method for LCA is needed. The additional effort for designers has to be kept to a minimum to avoid barriers for assessment. Therefore, tools for LCA should ideally be integrated in the usual design environment. Recently, various solutions to integrated LCA using BIM have been developed [5]. However, the conventional BIM is typically used in detailed design stages [6]. In early design stages, conceptional mass models are employed to quickly modify and generate variants at a low level of detail. Therefore, this paper discusses the use of simplified digital building models - referred to as early BIM-for LCA. The objective is to allow for time-efficient improvement of the environmental performance in early design at a point where many parameters needed for conventional BIM-LCA approaches are still unknown. The proposed approach is applied to a case study of the conceptional design of a neighbourhood.

\section{Early BIM-LCA Using Parametric Models}

The early BIM-LCA approach uses simplified digital building representations. These 3D models only consist of surfaces instead of volumetric components, see Fig. 1. This approach is also referred to as "shoebox" models [7] and is commonly employed in thermal models for energy demand calculation. The input of interior walls can be further simplified by using a global factor instead of modelling each individual wall, provided in Minergie guidelines [8], for example.

For a simplified input of materials, a building component catalogue of typically employed materials and heating, ventilation, and air conditioning (HVAC) systems

Fig. 1 Simplified building representation using surfaces only

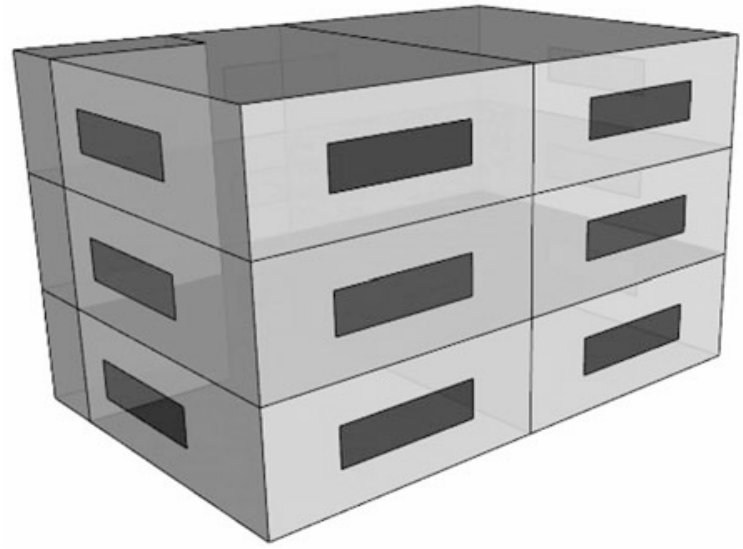


can be used. A variety of typical building components including LCA data can be found in many national catalogues, such as Bauteilkatalog [9] for Switzerland, Milieuprofiel van gebouwelementen [10] for Belgium, or Baubook [11] for Austria.

The calculation of the LCA is carried out using a parametric model [12]. The designer can typically influence three categories of parameters of a building: geometry, materials and HVAC systems [12]. Each category consists of a number of parameters, such as orientation, dimensions, window area, etc. for the geometry.

The parametric LCA approach combines the calculation of the operational and embodied environmental impact. The operational impact results from the use phase of the building (life cycle module B6 according to EN 15978 [13]) and is based on an energy demand calculation using monthly energy balancing [14]. The embodied impact results from the material production, replacements and the end-of-life (life cycle modules A1-A3, B4, C3, C4, and D). The implementation of the parametric LCA in a design tool such as Grasshopper [15] allows for a closed workflow of input, calculation, output without requiring any importing/exporting [16]. This is necessary for comparing variants automatically and is the basis for computational optimization approaches.

The parametric approach allows an advanced user to define and adjust their own weighting factors in order to consider the individual goals of the LCA study [16]. Furthermore, it allows for employing different predefined weighting factors, such as those from building certification systems. The DGNB system provided by the German Sustainable Building Council employs two criteria based on LCA and awards points for each [17]. These are weighted and combined into one indicator called life cycle performance (LCP) [18]. This single indicator ranges from 0 to 1 , with 1 being equal to $100 \%$ of the DGNB points related LCA criteria.

\section{Case Study}

In the following case study, the method is applied to the early design stages of a hypothetical residential neighbourhood providing a total gross floor area (GFA) of $2500 \mathrm{~m}^{2}$. Between two and four buildings are located on a rectangular site in Potsdam, Germany. The storey height of all apartments is $3 \mathrm{~m}$, and the buildings do not have basements. The floor area ratio (FAR) is set to 0.6 and minimum and maximum dimensions are set to ensure reasonable sizing of the building volumes. The buildings can have two to four floors and the glazing area is constantly $30 \%$ of the exterior wall area. It is assumed that the net floor area (NFA) equals $0.8 \times$ GFA. The functional unit is $1 \mathrm{~m}^{2}$ NFA for 1 year, and the reference study period is 50 years. Both climate and user data are taken from DIN V 18599-10:2011 [19].

It is assumed that the design process occurs in two stages, first definition of geometry, and second choice of materials. The HVAC systems are not modified parametrically but fixed. The heating system is set to a gas-condensing boiler with an efficiency of $98 \%$, no cooling is considered and the ventilation occurs naturally. 
For the first stage of defining the geometry, an algorithm positions buildings on the site. Due to the parametric positioning, it is likely that the buildings intersect initially. The algorithm resolves the intersections and maintains a pre-set minimum distance between the buildings [20]. A solar analysis is integrated to account for shading of the different buildings. Additionally, cores including the main circulation spaces within the buildings are inserted. In order to enable natural lighting and ventilation, they are only positioned at exterior walls, preferably in shaded areas to keep the solar gains to the usable floor spaces. If a building exceeds a defined building size, further circulation cores are added. The interior walls are not included in the 3D model, but instead inserted numerically based on a overall average factor of $0.4 \mathrm{~m} / \mathrm{m}^{2}$ GFA following the Swiss Minergie regulation [8]. All of those model features are parametrically controlled and each combination of the parameter values generates different design variants. The algorithm can quickly generate thousands of possible variants, which can be used for optimization [21]. The focus of the case study is the application of the early BIM-LCA method. Therefore, nine variants showing different geometric characteristics, such as number and position of buildings are chosen for stage 2 .

In the second stage, the resulting building volumes are combined with six different construction types. For each construction type four building componentsexterior walls, interior walls, ceilings, roofs - are manually generated, see Table 1. The individual materials of the constructions can be found in Table 2. The windows and the slab are the same for each construction type. The slab is made of reinforced concrete and polyurethane insulation; the windows consist of a PVC frame with double-glazing. The U-values for the building components of different construction types are the same and follow the minimum U-value of the 2014 German Energy Efficiency Regulation (EnEV) [22]. As such, the operational energy demand is only influenced by the geometry and not the thermal quality of the building envelope. Furthermore, all components possess a fire resistance of at least $60 \mathrm{~min}$. LCA data for the materials are taken from the German oekobau.dat database [23]. For each geometric variant, the calculation algorithm automatically runs a loop over the six different possible material combinations [18]. Finally, the LCP values for each variant are calculated.

Table 1 Different construction types

\begin{tabular}{l|l|l|l|l}
\hline Construction type & Exterior wall & Roof & Ceiling & Interior wall \\
\hline ETICS & ETICS & Concrete & Concrete & $\begin{array}{l}\text { Lime-sand } \\
\text { stone }\end{array}$ \\
\hline Brick & Insulated brick & Concrete & Concrete & Brick \\
\hline Concrete & Concrete & Concrete & Concrete & Concrete \\
\hline Wood & Wood frame & $\begin{array}{l}\text { Wood } \\
\text { beams }\end{array}$ & $\begin{array}{l}\text { Wood } \\
\text { beams }\end{array}$ & Wood frame \\
\hline Ventilated facade & Ventilated facade & Concrete & Concrete & $\begin{array}{l}\text { Lime-sand } \\
\text { stone }\end{array}$ \\
\hline $\begin{array}{l}\text { Double shell } \\
\text { masonry }\end{array}$ & $\begin{array}{l}\text { Double shell } \\
\text { masonry }\end{array}$ & $\begin{array}{l}\text { Wood } \\
\text { beams }\end{array}$ & Concrete & Wood frame \\
\hline
\end{tabular}


Table 2 Materials of the different building elements

\begin{tabular}{|c|c|c|c|}
\hline & Construction type & Material & $\begin{array}{l}\text { Thickness } \\
(\mathrm{cm})\end{array}$ \\
\hline \multirow{34}{*}{$\begin{array}{l}\text { Exterior } \\
\text { walls }\end{array}$} & \multirow{7}{*}{$\begin{array}{l}\text { External thermal insulation composite } \\
\text { systems (ETICS) }\end{array}$} & Synthetic plaster & 0.20 \\
\hline & & $\begin{array}{l}\text { Fibre glass reinforcement } \\
\text { grid }\end{array}$ & 0.05 \\
\hline & & Synthetic resin & 0.04 \\
\hline & & EPS & 13.00 \\
\hline & & Synthetic resin & 0.04 \\
\hline & & Lime-sand stone & 24.00 \\
\hline & & Gypsum plaster & 1.50 \\
\hline & \multirow[t]{3}{*}{ Brick } & Plaster & 2.00 \\
\hline & & Insulated brick & 26.00 \\
\hline & & Plaster & 2.00 \\
\hline & \multirow[t]{6}{*}{ Conrete } & Plaster & 0.20 \\
\hline & & $\begin{array}{l}\text { Fibre glass reinforcement } \\
\text { grid }\end{array}$ & 0.05 \\
\hline & & Synthetic resin & 0.04 \\
\hline & & EPS & 13.00 \\
\hline & & Synthetic resin & 0.20 \\
\hline & & $\begin{array}{l}\text { Concrete } \mathrm{C} 20 / 25,2 \text { vol\% } \\
\text { reinforcement }\end{array}$ & 15.00 \\
\hline & \multirow[t]{6}{*}{ Ventilated facade } & Wood cladding & 2.40 \\
\hline & & Wood laths 40/60 mm & $0.048^{\mathrm{a}}$ \\
\hline & & Sheathing membrane & 0.08 \\
\hline & & Rock wool & 11.00 \\
\hline & & Lime sand stone & 24.00 \\
\hline & & Plaster & 1.50 \\
\hline & \multirow[t]{8}{*}{ Wood frame } & Wood cladding & 0.20 \\
\hline & & Wood laths $40 / 60 \mathrm{~mm}$ & $0.048^{\mathrm{a}}$ \\
\hline & & Wood fibre board & 3.00 \\
\hline & & Gypsum plaster board & 0.95 \\
\hline & & Wood beam $12 / 18 \mathrm{~cm}$ & $2.16^{\mathrm{a}}$ \\
\hline & & $\begin{array}{l}\text { Wood fibre insulation } \\
\text { board }\end{array}$ & 11.00 \\
\hline & & OSB board & 1.80 \\
\hline & & Gypsum plaster board & 1.50 \\
\hline & \multirow[t]{4}{*}{ Double shell masonry } & Facing brick & 12.50 \\
\hline & & Cellulose insulation boards & 6.00 \\
\hline & & Brick & 24.00 \\
\hline & & Gypsum plaster & 1.50 \\
\hline \multirow[t]{3}{*}{ Roofs } & \multirow[t]{3}{*}{ Concrete } & Gravel 2/32 & 4.00 \\
\hline & & Bitumen sheeting & 0.80 \\
\hline & & XPS & 18.00 \\
\hline
\end{tabular}


Table 2 (continued)

\begin{tabular}{|c|c|c|c|}
\hline & Construction type & Material & $\begin{array}{l}\text { Thickness } \\
(\mathrm{cm})\end{array}$ \\
\hline & & Vapor barrier PA & 0.30 \\
\hline & & $\begin{array}{l}\text { Concrete } \mathrm{C} 20 / 25,4 \mathrm{vol} \% \\
\text { reinforcement }\end{array}$ & 20.00 \\
\hline & & Gypsum plaster & 1.50 \\
\hline & Wood beams & Bitumen sheeting & 0.80 \\
\hline & & $\begin{array}{l}\text { Wood fibre insulation } \\
\text { board }\end{array}$ & 18.00 \\
\hline & & Vapor barrier PA & 0.30 \\
\hline & & Wood planking & 2.40 \\
\hline & & Wood beam $12 / 18 \mathrm{~cm}$ & $2.16^{\mathrm{a}}$ \\
\hline \multirow[t]{14}{*}{ Cellings } & \multirow[t]{6}{*}{ Concrete } & Tiles & 1.00 \\
\hline & & Tile adhesive & 0.80 \\
\hline & & Cement screed & 6.00 \\
\hline & & Vapor barrier PE & 0.02 \\
\hline & & $\begin{array}{l}\text { Concrete } \mathrm{C} 20 / 25,4 \mathrm{vol} \% \\
\text { reinforcement }\end{array}$ & 18.00 \\
\hline & & Gypsum plaster & 1.50 \\
\hline & \multirow[t]{8}{*}{ Wood beams } & Parquet floor & 2.00 \\
\hline & & Dry screed & 2.50 \\
\hline & & $\begin{array}{l}\text { Wood fibre footstep sound } \\
\text { insulation }\end{array}$ & 2.00 \\
\hline & & Chipboard & 2.50 \\
\hline & & Wood beam $12 / 18 \mathrm{~cm}$ & 2.16 \\
\hline & & Vapor barrier PE & 0.02 \\
\hline & & Wood laths $30 / 60 \mathrm{~mm}$ & $0.036^{\mathrm{a}}$ \\
\hline & & Wood cladding & 2.40 \\
\hline \multirow{13}{*}{$\begin{array}{l}\text { Interior } \\
\text { wallls }\end{array}$} & \multirow[t]{3}{*}{ Concrete } & Gypsum plaster & 1.50 \\
\hline & & $\begin{array}{l}\text { Concrete } \mathrm{C} 20 / 25,4 \mathrm{vol} \% \\
\text { reinforcement }\end{array}$ & 10.00 \\
\hline & & Gypsum plaster & 1.50 \\
\hline & \multirow[t]{3}{*}{ Lime-sand stone } & Gypsum plaster & 1.50 \\
\hline & & Lime sand stone & 11.50 \\
\hline & & Gypsum plaster & 1.50 \\
\hline & \multirow[t]{3}{*}{ Brick } & Gypsum plaster & 1.50 \\
\hline & & Brick & 11.50 \\
\hline & & Gypsum plaster & 1.50 \\
\hline & \multirow[t]{4}{*}{ Wood frame } & OSB board & 1.80 \\
\hline & & Wood beam $6 / 8 \mathrm{~cm}$ & $3.00^{\mathrm{a}}$ \\
\hline & & Rock wool & 7.50 \\
\hline & & OSB board & 0.90 \\
\hline
\end{tabular}


Table 2 (continued)

\begin{tabular}{l|l|l|l}
\hline & Construction type & Material & $\begin{array}{l}\text { Thickness } \\
(\mathrm{cm})\end{array}$ \\
\hline \multirow{2}{*}{ Slabs } & \multirow{2}{*}{ Concrete } & Tiles & 1.00 \\
\cline { 3 - 3 } & & Tile adhesive & 0.80 \\
\cline { 3 - 3 } & Cement screed & 6.00 \\
\cline { 3 - 3 } & Vapor barrier PE & 0.02 \\
\cline { 3 - 3 } & XPS & 10.00 \\
\cline { 3 - 3 } & Bitumen sheeting & 0.40 \\
\hline & $\begin{array}{l}\text { Concrete C20/25, 4 vol\% } \\
\text { reinforcement }\end{array}$ & 25.00 \\
\cline { 3 - 4 } & Lean concrete & 8.00 \\
\hline
\end{tabular}

${ }^{\mathrm{a}}$ Equivalent thickness

\section{Results}

Combining nine geometric variants with six construction types results in 54 solutions. The results are visualized in a tree with two stages, see Fig. 2. The LCP show a high range of 0.376 between the minimum value of 0.580 (variant 7 , concrete) and the maximum value 0.956 (variant 3 , wood). The median of the six different construction types is calculated to evaluate the geometry independently from the choice of material. Variant 3 performs best according to the median LCP. Variant 3 also achieves the maximum overall performance in stage 2, when the wood-based construction variant is chosen. Variant 7 achieves least LCP according to the median and performs worst in both cases, when choosing wood or concrete.

The difference between the median of worst and best geometric variant is 0.17 showing that the influence of the geometry is significant. With a range of $0.22 \mathrm{LCP}$, the average range of the different material combinations is even higher. This clearly shows the great importance of the choice of material. The best solutions can be achieved with the wooden construction for all geometries in this case study. Even the worst geometric variant with wooden construction performs better than the best geometric variant built in ETICS, brick, concrete or a ventilated façade, see Fig. 3.

\section{Discussion}

The results highlight the importance of materials choices. In this case study, the median proves to be a robust indicator of the environmental performance in stage 2 . It can be used to evaluate and rank design solutions in stage 1 without having defined the exact material. This is important for application in practice, because usually there is no time for elaborate studies, such as presented here. A simple measure to indicate the environmentally best performing variants to the design team 


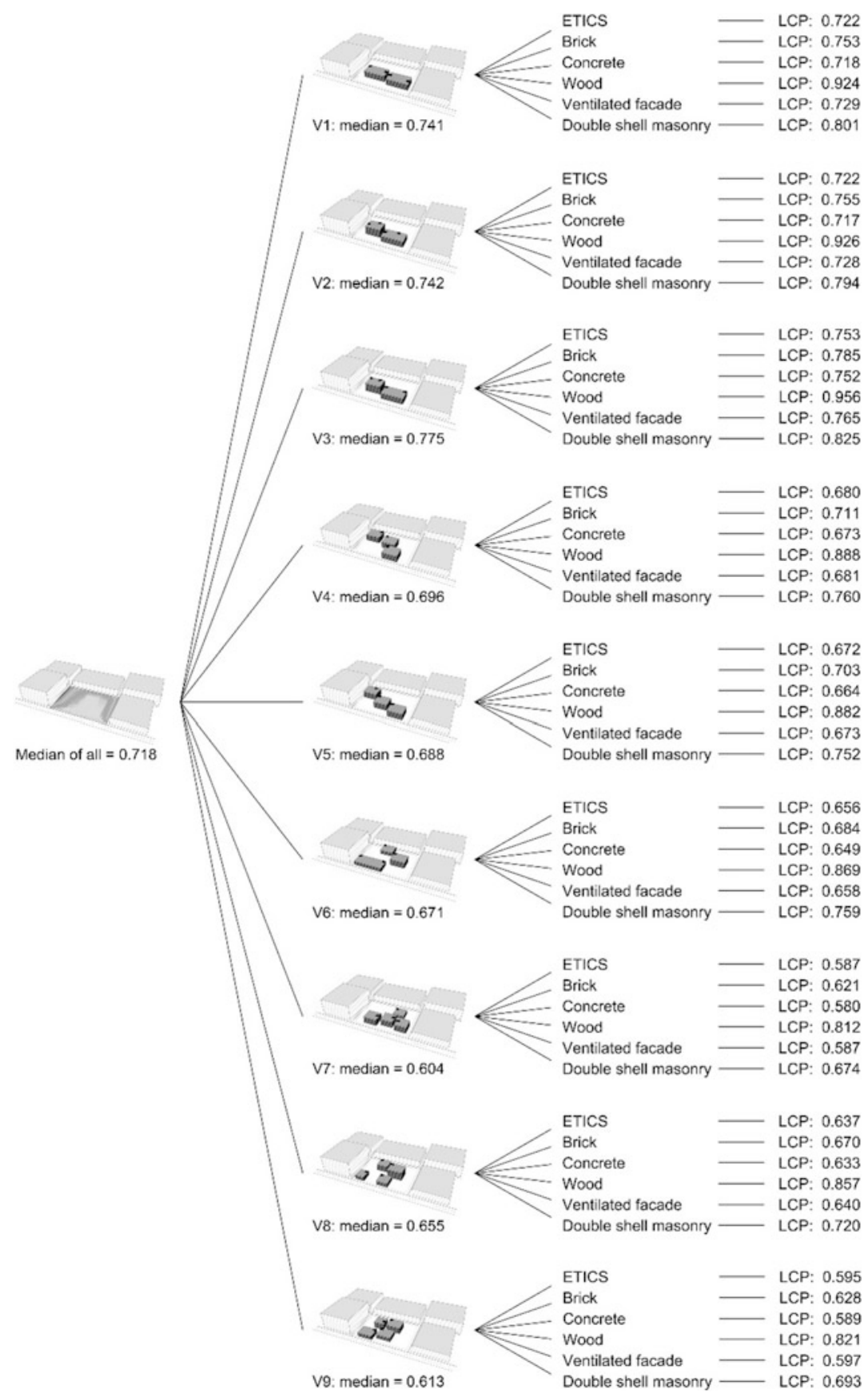

Fig. 2 LCP results for design tree 
Fig. 3 Ranges of material choice

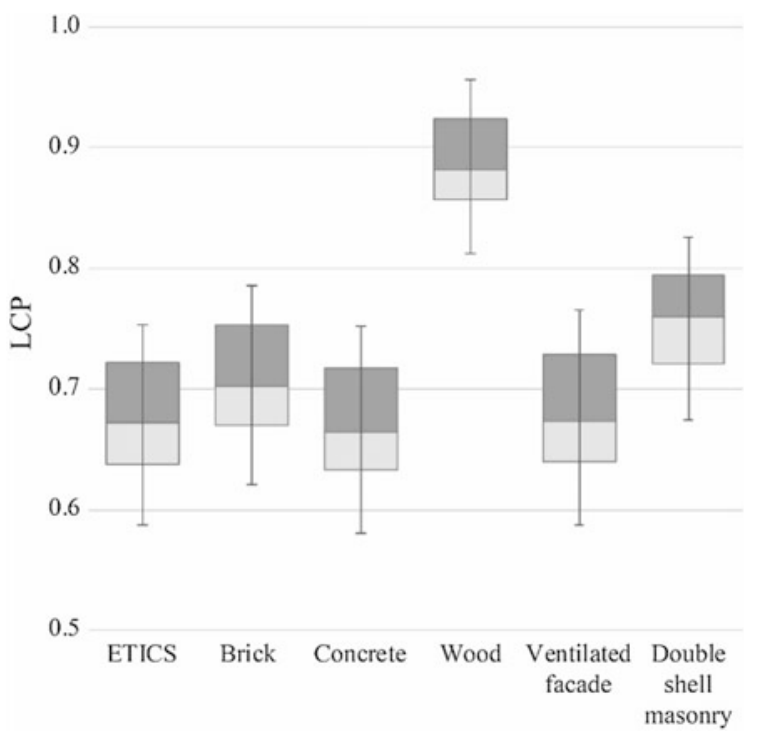

is needed. By automatically looping through a number of material variants and calculating the median this simple measure can be provided easily and time-efficiently. In the case study, each calculation took less than $0.1 \mathrm{~s}$, which allows to calculate the median within less than $0.6 \mathrm{~s}$. According to Nielsen [24] a response time of $1 \mathrm{~s}$ is acceptable for designers to not feel interrupted in their flow of thoughts. As such, the computer can loop through typical materials and provide an LCP before materials have been assigned. Using this measure, the designer can optimize the geometry without having information usually required for an LCA. Ideally speaking, this method frees the designer from worrying about HVAC systems and building materials in early design stages and allows focusing on the geometry.

In the case study presented here, the influence of the geometry was slightly smaller than the influence of the choice of material. However, the design space for the geometric variants was rather constrained. For simplification purposes, only cubic buildings with a fixed window to wall ratio and between two and to four floors have been generated. Increasing the variability of the geometry would clearly result in a higher influence of the geometry on the LCP. This would further highlight the strength of the presented approach of a combined assessment of geometry and material decisions in early design stages. 


\section{Conclusion and Outlook}

Design-integrated, simplified LCA based on digital building models can help to make informed environmental decisions during conceptual design. The early BIM-LCA approach using a parametric model presented here proves to be valuable for quick variant comparison of neighbourhoods in early design stages. The simplified visualization and the use of a single indicator can help designers to make informed decisions based on the LCA results. These simplified approaches are necessary to move from the current post-design evaluation of buildings to a design-integrated assessment. This finally allows designers to improve the environmental performance of their buildings from the very beginning of the planning process.

Through the development towards nearly zero energy buildings, buildings produce more and more of the energy they need for operation themselves. As such, the integration of local energy production should be integrated in the assessment. This aspect could be easily integrated in the parametric LCA model. Furthermore, the link to further analysis methods, such as daylight availability could provide a means to extend the early BIM-LCA to a more holistic performance evaluation tool in the future.

\section{References}

1. Wittstock B, Albrecht S, Makishi Colodel C, Lindner J. P, Hauser G, Sedlbauer K, Gebäude aus Lebenszyklusperspektive - Ökobilanzen im Bauwesen, Bauphysik, vol. 31, 2009.

2. Hegger M, Fuchs M, Stark T, Zeumer M, Energie Atlas: Nachhaltige Architektur. Birkhäuser, 2007.

3. Schneider C, Steuerung der Nachhaltigkeit im Planungs- und Realisierungsprozess von Büround Verwaltungsgebäuden. 2011.

4. Paulson Jr., B.C, Designing to Reduce Construction Costs, J. Constr. Div., vol. 102, no. 4, pp. 587-592, 1976.

5. Soust-Verdaguer B, Llatas C, García-Martínez A, Critical review of bim-based LCA method to buildings, Energy Build., vol. 136, pp. 110-120, 2017.

6. Köhler M, Rhinos, Hoppers, CAD-Monkeys, Competition online, pp. 85-90, 2016.

7. Dogan T, Reinhart C.F, Automated conversion of architectural massing models into thermal 'shoebox' models, BS2013 13th Conf. Int. Build. Perform. Simul. Assoc., pp. 3745-3752, 2013.

8. Minergie, Berechnung der Grauen Energie bei MINERGIE-A®, MINERGIE-ECO ${ }^{\circledR}$, MINERGIE-P-ECO® UND MINERGIE-A-ECO® BAUTEN, pp. 1-12, 2016.

9. Holliger Consult, Bauteilkatalog, 2002. [Online]. Available: http://www.bauteilkatalog.ch/ch/ de/Bauteilkatalog.asp. [Accessed: 08-Aug-2017].

10. Allacker K, et al., Environmental Profile of Building elements, Towards an integrated environmental assessment of the use of materials in buildings, 2013.

11. IBO, "baubook," 2014. [Online]. Available: www.baubook.at.

12. Hollberg A, Ruth J, LCA in architectural design — a parametric approach, Int. J. Life Cycle Assess., vol. 21, no. 7, pp. 943-960, Jul. 2016. 
13. CEN, EN 15978: Sustainability of construction works - Assessment of environmental performance of buildings - Calculation method. 2011.

14. Hollberg A, Lichtenheld T, Klüber N, Ruth J, Parametric real-time energy analysis in early design stages: a method for residential buildings in Germany, Energy, Ecol. Environ., Mar. 2017.

15. Rutten D, Grasshopper3D, 2015. [Online]. Available: http://www.grasshopper3d.com/. [Accessed: 08-Aug-2017].

16. Hollberg A, Parametric Life Cycle Assessment - Introducing a time-efficient method for environmental building design optimization. Bauhaus-Universitätsverlag, 2016.

17. German Sustainable Building Council, DGNB system, 2015. [Online]. Available: http://www. dgnb-system.de/en/. [Accessed: 08-Aug-2017].

18. Hollberg A, Klüber N, Schneider S, Ruth J, Donath D, A Method for Evaluating the Environmental Life Cycle Potential of Building Geometry," in Systems Thinking in the Built Environment. Sustainable Built Environment (SBE) Regional Conference Zurich 2016, 2016, pp. 590-595.

19. DIN, DIN V 18599-10:2011 Energetische Bewertung von Gebäuden - Berechnung des Nutz-, End- und Primärenergiebedarfs für Heizung, Kühlung, Lüftung, Trinkwarmwasser und Beleuchtung - Teil 10: Nutzungsrandbedingungen, Klimadaten. DIN Deutsches Institut für Normung e. V., pp. 1-102, 2011.

20. Tschetwertak J, Schneider S, Hollberg A, Donath D, Ruth J, A Matter of Sequence Investigating the Impact of the Order of Design Decisions in Multi-Stage Design Processes, in Computer-Aided Architectural Design Future Trajectories 17th International Conference, CAAD Futures 2017 Istanbul, Turkey, July 12-14, 2017 Selected Papers, G. Çağdaş, M. Özkar, G. Ethem, and L. F. Gül, Eds. Springer Nature Singapore Pte Ltd., 2017, pp. 100-120.

21. Tschetwertak J, Schneider D, Hollberg A, Donath D, Ruth J, Does the sequence matter? Investigating the impact of the order of design decisions on the Life Cycle Performance, in World Sustainable Built Environment Conference 2017 Hong Kong, 2017, no. June, pp. 1933-1938.

22. Bundesregierung, EnEV 2014: Energieeinsparverordnung - Nichtamtliche Lesefassung zur Zweiten Verordnung zur Änderung der Energieeinsparverordnung vom 18. November 2013. Germany: Bundesanzeigerverlag, 2013, pp. 1-90.

23. BBSR, ökobau.dat. Bundesministerium für Umwelt, Naturschutz, Bau und Reaktorsicherheit, 2015.

24. Nielsen J, Usability Engineering. Academic Press, 1993.

Open Access This chapter is licensed under the terms of the Creative Commons Attribution 4.0 International License (http://creativecommons.org/licenses/by/4.0/), which permits use, sharing, adaptation, distribution and reproduction in any medium or format, as long as you give appropriate credit to the original author(s) and the source, provide a link to the Creative Commons license and indicate if changes were made.

The images or other third party material in this chapter are included in the chapter's Creative Commons license, unless indicated otherwise in a credit line to the material. If material is not included in the chapter's Creative Commons license and your intended use is not permitted by statutory regulation or exceeds the permitted use, you will need to obtain permission directly from the copyright holder.

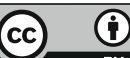

